\title{
DESIRING THE HIDDEN GOD: KNOWLEDGE WITHOUT BELIEF
}

\author{
JULIAN PERLMUTTER \\ University of Cambridge
}

\begin{abstract}
For many people, the phenomenon of divine hiddenness is so total that it is far from clear to them that God (roughly speaking, the God of Jewish and Christian tradition) exists at all. Reasonably enough, they therefore do not believe that God exists. Yet it is possible, whilst lacking belief in God's reality, nonetheless to see it as a possibility that is both realistic and attractive; and in this situation, one will likely want to be open to the considerable benefits that would be available if God were real. In this paper I argue that certain kinds of desire for God can aid this non-believing openness. It is possible to desire God even in a state of non-belief, since desire does not require belief that its object exists. I argue that if we desire God in some particular capacity, and with some sense of what would constitute satisfaction, then through the desire we have knowledge - incomplete yet vivid in its personal significance - about the attributes God would need in order to satisfy us; thus, if God is real and does have those attributes, one knows something about God through desiring him. Because desire does not require belief, neither does the knowledge in question. Expanding on recent work by Vadas and Wynn, I sketch the epistemology of desire needed to support this argument. I then apply this epistemology to desire for God. An important question is how one might cultivate the requisite kinds desire for God; and one way, I argue, is through engaging with certain kinds of sacred music. I illustrate desire's religiously epistemic power in this context, before replying to two objections.
\end{abstract}

\section{TYPES OF DIVINE HIDDENNESS AND FRAMING THE ARGUMENT}

Two problems have been called 'the problem of divine hiddenness'. One is the widespread non-belief in God's existence among those who are not resistant to relationship with God, which has been used, primarily by John Schellenberg, to argue that God as traditionally conceived 
does not exist. The other 'problem of divine hiddenness' is God's nonmanifestation to believers. The first is an evidential problem for theists in general: the fact that there are non-resistant people who don't believe in God's existence is taken as evidence of his non-existence. The second is a spiritual problem for theists who, at least at times, do not seem to experience God.

My focus is different again. I am interested in a particular kind of cognitive and affective situation: a specific kind of situation within the broad kind that concerns Schellenberg. The broad kind is that of someone for whom it is far from clear that the God of Jewish and Christian tradition exists, and who therefore does not believe he exists. Within this, the specific kind of situation that interests me is of someone who, whilst uncertain over God's reality, nonetheless sees God's existence as a live hypothesis (in William James' sense) ${ }^{1}$ and even an attractive one. Such a person will want to be open to the inestimable benefits that would be available if God were real (i.e., be able to receive and live out those benefits), and I shall argue that certain forms of belief-less desire for God can play a role in this. If God is real, then one can know about him in desiring him. Rightly ordered desire can thereby start to familiarise the desirer with God's nature, direct her towards him, and propel her onwards in the spiritual quest.

Thus, we are concerned with the possibility of God's reality: specifically, how one's desire for God can help one to be open to benefits that would be available if he were real. Since Schellenberg's divine hiddenness argument seeks to dispense with the possibility of God's reality, I'll proceed on the contentious assumption that the argument is flawed. ${ }^{2}$ But even if non-resistant non-belief turns out not to be evidence

${ }^{1}$ A live hypothesis is one which appeals as a real possibility to him to whom it is proposed'; it makes an 'electric connection with [one's] nature' and 'scintillate[s] with ... credibility'. William James, 'The Will to Believe', in The Will to Believe and Other Essays in Popular Philosophy (New York, NY: Longmans Green and Co, 1897), p. 2.

${ }^{2}$ The general shape of Schellenberg's argument, and of my case against it, are as follows. Schellenberg argues that if God - characterised as unsurpassably loving - existed, then anyone who tried to have a personal relationship with him would at that time be able to do so, and would therefore at that time believe he exists. But some people try to have a personal relationship with God, yet do not believe God exists; therefore, God does not exist. See J. L. Schellenberg, 'Divine Hiddenness and Human Philosophy', in Hidden Divinity and Religious Belief: New Perspectives, ed. by Adam Green and Eleonore Stump (Cambridge: Cambridge University Press, 2016), pp. 13-32 (the version consulted here is an online manuscript, accessed 4th April 2016, http://www.jlschellenberg.com/ 
against God's existence, many are still left with insufficient reason to believe. If 'doxastic divine hiddenness' is not an evidential problem for theists, it is still a spiritual problem for those interested in religious belief but unable to believe, since on the face of it, it is hard to see how one who does not believe in God's existence might remain open to the benefits that would be available if he were real.

As a way out of this problem, I submit that it is indeed possible to cultivate some amount of openness to God without believing he exists. One can desire God without belief in this sense, since in general it is possible to desire something without believing it exists. In what follows I'll argue that under certain conditions, one can know in desiring God something of what he would be like in satisfying the desire; thus, if God is real and would satisfy the desire, one knows something about God in this capacity, where this knowledge is available even in the absence of satisfaction and is therefore imbued with a certain kind of existential significance. (Note that I do not say the desire is evidence for God's reality; rather, it is a way of knowing about God if he is real.) The desire thus helps establish an epistemic and affective framework for seeking God. My claim therefore forms part of a wider suggestion to those in the situation I have described: engage non-doxastically in religious practice - not, as Pascal urged in the context of his 'wager', to acquire beliefs that one already wants to hold, ${ }^{3}$ but rather to give one's awareness the chance to shift in ways perhaps unforeseeable.

When I come to discuss desire-based knowledge about God, I will do so in the particular context of sacred music. Sacred music has the power

uploads/8/5/6/1/8561683/divine_hiddenness_and_human_philosophy.pdf). I contend that the existence of an unsurpassably loving God is compatible with non-belief among those who try for a relationship with him. We'd expect God to seek relationship with everyone - thus enabling belief in every non-resistant person - in this life, since we think we would in his situation. But unsurpassable love only requires God to seek relationship ultimately with everyone, even if only after death, thus ultimately enabling belief in every non-resistant person - which for all we know may be the case. There may be reasons incomprehensible to us as to why, for some non-resistant people, God is open to full relationship only in the afterlife. He might therefore prevent such people from believing in his existence during their earthly lives. If we cannot comprehend why God wouldn't be open to full relationship with some people in this life, then non-resistant non-belief and non-relationship are surprising given his existence. But things that are surprising given God's existence are compatible with his existence, since we cannot expect to know everything about his workings.

${ }^{3}$ Blaise Pascal, Pensées, trans. by A. J. Krailsheimer, revised edition (London: Penguin, 1995), pp. 124-5, no. 418. 
to move us profoundly - something often true even of non-believers. ${ }^{4}$ One way it can do this for non-believers is by eliciting desire for God, since desire does not require belief that its object exists. There are many sacred works whose music and text can elicit desire for God, and I'll discuss one especially powerful example: Henry Purcell's anthem Hear My Prayer, O Lord. I'll argue that by eliciting a desire for God that satisfies certain conditions, sacred music can engender the kind of desire-based knowledge about God that I've mentioned, which does not require belief in God's reality.

\section{DESIRE AS KNOWLEDGE ABOUT THE DESIRED}

To show that religious desire can play the role I have outlined, I'll first discuss some non-religious desires, highlighting how they enable knowledge about their objects. Non-religious examples will clarify the epistemically important features of desire, since these features are more clear-cut in such cases than in religious contexts. Once we're clear on the phenomenology and conditions of desire-based knowledge as I present it, we'll turn to their religious application.

We can start with an observation made by Melinda Vadas: desire is both a present affect and a projection of affect, which are phenomenologically inseparable. In desiring something, I predict I will feel a certain way if satisfied. ${ }^{5}$ Mark Wynn develops this insight in relation to the desire for musical resolution, pointing out that here the desire itself gives the desirer knowledge about its object by casting the mind forwards:

on account of its felt recognition of the tension, the mind is cast forward, in desire, to an anticipated moment of 'resolution' ... the character of this resolution is grasped not musicologically, or in purely auditory terms (after all, it is not available to be heard as yet), but by way of the felt yearning or longing which points ... towards what is required if a resolution of this particular musical tension is to be achieved. ${ }^{6}$

${ }^{4}$ As David Pugmire observes, 'Sacred music seems to have a surprising power over unbelievers ... to ply them ... with what might be called devotional feelings.' See David Pugmire, 'The Secular Reception of Religious Music', Philosophy 81, no. 1 (2006), 65.

${ }^{5}$ Melinda Vadas, 'Affective and Non-Affective Desire', Philosophy and Phenomenological Research 45, no. 2 (1984), 276-7.

${ }^{6}$ Mark Wynn, Emotional Experience and Religious Understanding: Integrating Perception, Conception and Feeling (Cambridge: Cambridge University Press, 2005), p. 106 (emphasis added). 
In feeling the desire, one is aware of how a satisfying musical resolution would sound. The desire therefore brings with it a kind of knowledge of the resolution's nature before it happens.

Let's look more closely at this sort of experience. The first thing to notice is that the desire for musical resolution is for something in a particular capacity - for a chord or note in the capacity of resolving musical tension. The knowledge the desire enables in Wynn's example is knowledge of what something would be like in the capacity of providing satisfaction. With this established, I'll now turn to another form of desire: desire for food. As certain Biblical passages highlight, this can be phenomenologically similar to the desire for God, and it can thus help us develop an epistemology of desire applicable to God. ${ }^{7}$ My concern here is the desire for some particular kind of food rather than general hunger; and although Biblical hunger-based analogies for desiring God relate more to the general desire for sustenance or nourishment than to desires for particular foods, these need not be distinct. This is obvious in the case of food (a desire for a particular food can be a desire for nourishment), but it is also true of desire for God: desiring God in some particular capacity can be seen as desiring some particular aspect of his nourishment or sustenance. Thus, Biblically depicted hunger for God can be phenomenologically similar to the desire for food I use in developing my epistemology.

The desire I have in mind, then, is for some specific food or other. We have all found ourselves in the mood for a particular food - a buttery cinnamon bagel, a juicy strawberry, or whatever it might be. Desiring food in this way, one senses what would constitute satisfaction - including tasting the food's flavour and feeling its texture and temperature in one's mouth. Through this sense as experienced with the desire, one can 'practically taste' the food in question, and this enables knowledge of the kind Wynn describes: the aspects of the food that one knows

${ }^{7}$ The analogy between hungering for food and desiring God is highlighted at certain points in the Bible. In the Old Testament, see for instance Amos 8:11: "Behold, the days are coming," declares the Lord God, "when I will send a famine on the land - not a famine of bread ... but of hearing the words of the Lord ... " And in the New Testament, John's Gospel is especially noteworthy for its language of hunger and food regarding God. See Jesus' 'I am the bread of life' address in John 6:22-59, which recapitulates and extends the theme, from the book of Exodus, of the bread that comes from heaven. Biblical translations (except for that used in Purcell's piece to be discussed later) are from the English Standard Version Anglicised. 
about through desiring it are those that would bring about what, one senses, satisfaction would involve - for instance, its flavour, texture, and temperature. A vivid example of this can be found in Leo Tolstoy's Anna Karenina. In one scene, the protagonist Levin has returned from a hunting trip 'tired and hungry', only to find that his companions have finished off all the provisions. The passage continues, 'Levin had been dreaming so specifically of pirozhki [stuffed buns] that, as he approached their quarters, he could already feel their smell and taste in his mouth.' ${ }^{8}$ In the event, Levin does not have the satisfaction of tasting the pirozhki; yet his knowledge of their smell and taste is certainly heightened by his desire for them. We see, then, that desiring to eat a particular food can give the desirer knowledge of what it would be like in the capacity of providing satisfaction. Moreover, because of its inherent sense of lack, this knowledge involves an especially clear recognition of the food's importance to oneself as the desirer.

Now clearly one's sense of what would satisfy the desire is based on past experience: one cannot imagine eating a particular food if one has no experience along those lines. But one need not have experienced anything exactly like the projected satisfaction: to imagine what it would be like, it is enough to have had experience somewhat like it. I have eaten mango, dark melted chocolate, and solid mint chocolate all separately, but I have never eaten mango covered in melted dark, mint chocolate. Nonetheless, I desire this combination; if I think of it, I can form a sense of how it would taste and feel in my mouth. This sense of what would constitute satisfaction is based on my imaginative powers and an amalgamation of memories, and so the example shows that desire-based knowledge can be rooted in experience merely analogous to whatever would constitute satisfaction. This is important for knowing about God through desiring him, since in many cases one will not have fully experienced the satisfaction from him for which one yearns.

It is worth supplementing this account with another kind of desire that shares phenomenological features with desire for God: romantic desire. Like desire for God, this is felt towards a person and would be satisfied by something more than sense experience (even if satisfaction were to come through sense experience). Romantic desire is another kind that can give the desirer knowledge as I have been describing it.

${ }^{8}$ Leo Tolstoy, Anna Karenina, trans. by Richard Pevear and Larissa Volokhonsky, revised edition (London: Penguin, 2003), p. 596. 
Its affectivity permeates our concepts of the attributes through which (we sense) we would be satisfied. For instance, our notion of 'intimately loving and supportive' acquires a hue of emotional significance in light of our desire and our sense of what would constitute satisfaction: we know how these attributes matter to us in a romantic context. And our knowledge of what the attributes would be in contributing to our satisfaction is thus deepened.

We can now state the conditions for the desire-based knowledge I've described. First, the desire must be for something in a particular capacity; hence, the knowledge is of what something would be like in the capacity of providing satisfaction. Second, one needs some sense of what would constitute satisfaction; and the aspects of the desire's object that one knows about through the desire are those that would bring about this projected satisfaction. And third, in order to have this sense, one must have experienced at least something like the projected satisfaction. Note that belief in the existence of what one desires is not needed for any of these conditions. The knowledge may take the propositional form, 'if $x$ existed, $x$ would be such-and-such in satisfying my desire', where 'such-and-such' denotes attributes grasped in terms of their importance to the desirer.

With these conditions in mind, we can now turn to desire for God.

\section{KNOWING ABOUT GOD THROUGH DESIRE: A MUSICAL EXAMPLE}

Desire for God, like other desires, can come in degrees of specificity; and it should now be clear that to enable knowledge about God in the way described, a desire must be rather specific. Therefore, to shed light on desire's religiously epistemic power along the lines we've explored, we must consider specific forms of desire for God; and I'll now consider how one such form of desire can yield a particular content of theistic knowledge. What I say will illustrate how desire can work epistemically in a religious context, and the general epistemic components would therefore apply to many other specific forms of religious desire.

One kind of experience that can elicit a longing for God is engagement with sacred music. I do not claim that all sacred music does so; such music can express and elicit many affective states. But I take it that one natural response to sacred music is a longing for the fullness of that transcendence at which it so often seems to hint. This is because of 
music's capacity for beauty, and also because of how it can combine with text to achieve nuanced and specific expression: through presenting in a certain way a text that expresses a specific form of desire for God, music can elicit a specific form of desire in the listener. I'll now briefly consider the epistemic capacity of the desire for God in one especially powerful sacred anthem: the desperate cry of Purcell's Hear My Prayer, O Lord. ${ }^{9}$ The listener's response I'll describe is simply an example of the religious desire that sacred music may plausibly elicit, in order to illustrate music's ability to elicit desire for God, and desire's ability to yield knowledge about God.

The text of the piece opens Psalm 102: 'Hear my prayer, O Lord, and let my crying come unto thee'. Purcell's extraordinary music, in its slow build to a final, anguished climax, combines with the text to express a heart-rending longing for God in human distress - i.e., for God in the capacity of compassionately hearing and supporting. The piece does not elicit this precise yearning in the listener, since it cannot bring about the distress that is central to such yearning (one would hope not, at any rate). However, it can elicit a corresponding desire. Empathising with the psalmist, one recognises one's own capacity to reach in desperate situations for 'something more'; and, given that this recognition is brought on by a piece of Christian sacred music, one will likely think of this 'something more' as the God portrayed in the piece - the God of Jewish and Christian tradition. The listener's response I have in mind, then, is an analogue of desperation: by recognising our capacity for desperation before God, we experience something of that desperation without feeling it fully. This is possible because neither Purcell's music nor the psalmist's text refers to any unfortunate circumstance. ${ }^{10}$ Although the piece expresses distress

\footnotetext{
9 There are recordings readily available online, for example at https://www.youtube.com/watch?v=o8E0dt0soWc (accessed 4th April 2016).

${ }^{10}$ For music's inability to refer to specific kinds of circumstance, see, e.g., Aaron Ridley, Music, Value and the Passions (Ithaca, NY: Cornell University Press, 1995), pp. 110-13. The wider context of Ridley's view is an account of how music can be expressive of affective states, known as the 'resemblance theory': according to this account, music is expressive of affective states by resembling human expressive behaviour - particularly voice and movement. See ibid., chap. 4; and see also James O. Young, Critique of Pure Music (Oxford: Oxford University Press, 2014), pp. 15-26, for an array of psychological evidence in support of the theory. However, regardless of whether or not one endorses the resemblance theory, it is hard to see how Purcell's music, or any other music, can refer to any particular kind of circumstance; and, given that the text of the piece clearly does not do so either, the piece as a whole cannot refer to any unfortunate circumstance.
} 
and thus implies some unfortunate circumstance, it is perfectly possible to listen to the piece and not have any misfortune called to mind. Thus, unlike true desperation, the analogue of desperation before God that Purcell's piece can elicit is not felt about any unpleasant circumstance, and is therefore not itself unpleasant.

In this way, without feeling the full force of the psalmist's desperation, one grasps enough of it to form some sense of what would satisfy it based on past experience of that satisfaction or on analogous experience (typically from interpersonal relationships, where another human being has provided comfort and support in a time of distress). Satisfaction here - an answer to the desperation in Purcell's piece - would involve a profoundly changed, hopeful perspective, a sense of widened possibilities. The attributes God would need for effecting this include deep resourcefulness - enabling him to see hope in an apparently hopeless situation - and the power to convey this hope lovingly to the sufferer. Or to use Rowan Williams' words, in order to satisfy the desperation in Purcell's piece, God would need the power to '[open] the door to a future even when we can see no hope. It would have to be the case that 'there is nowhere God is absent, powerless or irrelevant; no situation in the universe in the face of which God is at a loss ... God always has the capacity to do something fresh and different, to bring something new out of a situation.. ${ }^{11}$ Through desiring God in the way I have described, then, one's notions of attributes such as 'deeply resourceful', 'loving', and 'supportive' acquire a hue of emotional significance in light of the desire and the sense of what would constitute satisfaction: one knows how those attributes matter to oneself in a religious context. And one thereby knows with particular existential sharpness something of what God's nature would be in satisfying the yearning, a sharpness heightened by the lack of God's tangible presence at that time. Thus, if God is real and has that nature, one knows something about God through desiring him.

\section{TWO OBJECTIONS}

Objection 1: Can we sense what divine satisfaction would involve without any past experience of it?

I said that in having some sense of what it would be like to be satisfied in the

${ }^{11}$ Rowan Williams, Tokens of Trust: An Introduction to Christian Belief (London: Canterbury Press Norwich, 2007), pp. 44, 16. 
psalmist's desperate yearning for God, one can refer to past experiences of one's own that were analogous to that satisfaction - notably from interpersonal relationships, where another human provided comfort and support in a time of distress. But it might be objected: can we really have, on the basis of our worldly experience, any sense of what would constitute divine satisfaction, and thus knowledge of what God would be like in granting it? Indeed, this objection might be applied not just to the desiring response to Purcell's piece described above, but to desire for God in general. In support of this attack, one might refer to what have become known as 'transformative experiences', roughly characterisable for our purposes as experiences that effect changes in the subject - changes that, in at least some cases, could not have happened in any other way. In a recent paper, L. A. Paul has argued that one such kind of experience is that of having a child; more specifically, this is both epistemically and personally transformative. ${ }^{12}$ That is, the experience of having a child gives a person knowledge of what it is like to have a child, knowledge unavailable to one who remains childless; moreover, it radically changes what it is like to be the person in question. ${ }^{13}$ Importantly, there are no other experiences that, were one to have them, would allow one to project forward with any accuracy to a sense of what it would be like to have a child of one's own. Any analogous experience one might have (such as looking after other children) is simply not similar enough. ${ }^{14}$

But (the objector might continue), isn't an experience of God similar in this way to that of having a child? The philosopher Thomas Morris no doubt speaks for many believers when he writes that 'the Christian faith ... has on occasion turned my little world upside down. ${ }^{15}$ Surely it is impossible, before experiencing God in such a radically transformative way, to know anything of what it will be like? After all, such an experience is a complete re-ordering of one's priorities, and of where one's worth as a person seems to originate (the experience will likely be diachronic, developing over time). It is, so to speak, the inhabiting of a different paradigm, which gives other experiences a significance they would

${ }^{12}$ L. A. Paul, 'What You Can't Expect When You're Expecting', Res Philosophica 92, no. 2 (2015), see esp. pp. 153-62.

${ }^{13}$ Ibid., pp. 156-7.

${ }^{14}$ Ibid., p. 161.

15 Thomas V. Morris, 'Suspicions of Something More', in God and the Philosophers: The Reconciliation of Faith and Reason, ed. by Thomas V. Morris (New York, NY: Oxford University Press, 1995), pp. 8-9. 
not otherwise have had. How, then, could anything prior to such an experience of God give a clue as to what it would be like? And to round off the objection, we can situate any experience that seems to come from God - including satisfaction of the desire expressed in Purcell's piece - within this understanding of what it is to experience God. If, so our objector will claim, the profoundly changed, hopeful perspective that would satisfy the psalmist's yearning seems to come from God, then it will get whatever significance it has from a wider conception of God's priorities and of how they relate to one's own life. But if one has not already experienced (or seemingly experienced) these things, then one cannot begin to conceive of them - and this makes it impossible to conceive of what it would be to have a changed perspective that seems to come from God, and which satisfies the kind of desperation expressed in Purcell's piece. If one has not had a transformative theistic experience, then one cannot form any remotely accurate sense of what the satisfaction of the psalmist's desire would be like. ${ }^{16}$

To this objection, we can reply as follows. According to a prominent characterisation in the Christian tradition of how experiences of God relate to other experiences, there are experiences that can help one to form a somewhat accurate sense of what it would be like to experience God in various ways. This way of thinking has its roots in the Bible, for example in the first Johannine epistle's affirmation that 'love is from God, and whoever loves has been born of God and knows God.'17 And we find similar ideas elsewhere - Aquinas, for instance, stating that 'we know [God] accordingly as He is represented in the perfections of creatures. ${ }^{18}$ In short, the idea is that from our engagement with others, we can know to some extent what it would be like to relate to God. Moreover, L. A. Paul's example shows that this includes knowledge of what it is like to be personally transformed, in ways that are analogous to the transformations in the life of a believer - such as having one's priorities re-ordered and having another person at the centre of one's life. Having a child is one example, but there are of course others, such as getting married.

\footnotetext{
${ }^{16}$ I thank Joshua Cockayne and Amber Griffioen for raising this objection.

171 John 4:7.

18 Thomas Aquinas, Summa Theologica, trans. by Fathers of the English Dominican Province, online (Kevin Knight, 2008), I, Q13, A2, ad 3, accessed 5th April 2016, http:// www.newadvent.org/summa/index.html.
} 
When one engages with the 'live hypothesis' of God's existence within this mode of thinking, the following line of reasoning becomes apposite. If (a) we can know something of what relationship with God is like through our relationships with other people, and if (b) we desire God in a capacity somewhat similar to the ways in which we have experienced interpersonal relationships, then we can know, based on our experience of the world and an imaginative leap, something of what God would be like in satisfying our desires for him. To take the Purcell case: we know that in satisfying our desire for a compassionate presence, humans are loving, supportive, and resourceful, opening up possibilities for hope where we saw none; and we are also familiar with the relational context of the person's concern for us, which gives this changed, hopeful perspective its significance. If we combine our experience of human love, support, and resourcefulness with the idea of God as infinitely resourceful (we might see this as an aspect of his omnipotence), then we can form some sense of what it would be like to be on the receiving end of God's resourcefulness - for instance, by imagining having hope opened up for us where no human being could have done so. And to imagine this is just to imagine what it would be like to experience this infinite resourcefulness - i.e., to imagine something of what this infinite resourcefulness is like. If one does this in the midst of a desire for God that is centred on such resourcefulness, then one's (partial) knowledge of what it would be like to experience it will be shot through with personal, emotional significance in the way already described. It is worth stressing once more that none of this presupposes any belief in the reality of such divine resourcefulness. The desire-based knowledge may take the propositional form, 'if God existed, God would be infinitely resourceful in satisfying my desire', where 'infinitely resourceful' denotes a divine attribute grasped in terms of its special importance to the desirer.

\section{Objection 2: Isn't this all just wishful thinking?}

Even if it is possible, without past experience of divine satisfaction, to have a sense of what that satisfaction would be like, there remains another danger. For couldn't this all be just so much wishful thinking? If one has a desire that is directed at God as one conceives of him, along with a sense of what would constitute satisfaction and resultant, 'existentially sharp' knowledge of what God would be like in granting that satisfaction, couldn't this simply be a matter of knowing how one 
would like God to be in satisfying one's desire, with no correspondence to God's actual nature if he is real? ${ }^{19}$

In order for a desire to enable the kind of knowledge described here about a God who were real, that desire's satisfaction would need to be something that such a God would bring about: in other words, the desire would need to be rightly ordered towards God. It is true, of course, that desire can go wayward, and this is perhaps especially so of desire for God: here there is an ever-present risk of '[using] God to fill the gaps in our needs and preferences' 20 - a risk of forming ideas about God based on what we think he ought to do for us (one might, for instance, desire success, and take God to be one who would grant such a desire).

Part of the point in discussing Christian sacred music was to show one way of ordering one's desires towards things that God, as conceived in the Christian tradition (including its roots in the Hebrew Bible), could be hoped to grant if he were real. As we have seen, because of its capacity to shape a desire with both a specific affective colour and the conceptual content of the text, music is well placed to do this. And in general, one can engage in the Church's music and liturgy, as well as in other practices such as regular meditation or prayer; and this can all happen alongside continued theological reflection on God's nature in light of certain core, definitional divine attributes and the experiences of the tradition's 'cloud of witnesses'. If one does this with a degree of fruitfulness, then there is some hope that one will come to have desires whose satisfaction really would be granted by the God to whom all this engagement points; and these desires would thereby be focused on God as he has been characterised within the tradition in its more spiritually mature forms. The knowledge resulting from such desires would then be about this sort of God - and it is this sort of knowledge, I take it, that one would be pursuing in the situation I outlined at the start of the paper, in which the existence of such a God is a live hypothesis.

\section{CONCLUSION: DIVINE HIDDENNESS AND FRAMEWORKS FOR SEEKING}

I started by describing the sort of situation that concerns me in which God seems hidden: that of not being persuaded of the truth of a given

\footnotetext{
${ }^{19}$ My thanks go to Sameer Yadav for raising this objection.

${ }^{20}$ Williams, Tokens of Trust, p. 157.
} 
theistic worldview because one does not see enough evidence for it, but of nonetheless being interested in that worldview and wanting to remain open to the potential benefits that would flow from its truth. I also said that if God is real, then desire-based knowledge about him can further this openness by establishing an epistemic and affective framework for seeking him. How does this claim relate to the foregoing exploration of religious desire? Through the desiring response to Purcell's piece that I described, one knows something of what God would be like if he were to satisfy the desire (the epistemic framework). The existential significance that permeates this knowledge and enriches one's concepts of the relevant divine attributes will draw one into seeking God more than a thinner understanding of those attributes would. The spiritual quest has personal import (the affective framework). The desperate yearning of Purcell's piece is one of many different kinds of longing for God; and we can note the power of sacred music to elicit a huge variety of them. Other forms of desire will enable knowledge about different divine attributes depending on what would constitute satisfaction, and will frame one's religious engagement accordingly. It should be clear, then, that desire for God in its various forms has a tremendous capacity to ignite, shape, and sustain a journey of religious openness. Because one can desire God without believing in his existence, this journey, and the desire-based knowledge that fuels it, are available even to those from whom God seems too hidden for belief to be a possibility. ${ }^{21}$

${ }^{21}$ This paper was written with the support of an Arts and Humanities Research Council Doctoral Studentship. 